\title{
Insulin Resistance Predicts the Effectiveness of Different Glycemic Index Diets on Weight Loss in Non-Obese Women
}

\author{
Mauro Felippe Felix Mediano ${ }^{a}$ Rosely Sichieri ${ }^{a}$, b \\ ${ }^{a}$ Department of Clinical and Experimental Medicine, ${ }^{b}$ Department of Epidemiology, Institute of \\ Social Medicine, State University of Rio de Janeiro, Rio de Janeiro, Brazil
}

\section{Key Words}

Obesity $\cdot$ Overweight $\cdot$ Nutrition $\cdot$ Prevention $\cdot$ Insulin resistance

\begin{abstract}
Objective: The present study aimed to evaluate whether baseline insulin resistance (IR) modify weight change associated to glycemic index (GI) of the diet. Method: This is a secondary analysis of a randomized GI intervention according to baseline HOMA-IR. Middle-aged (2545 years), non-obese (BMI 23-29.9 kg/m²) women were randomized to low or high GI diets matched on total energy, macronutrient composition, and fiber content. Both groups received dietary counseling based on a small energy restriction (100-300 kcal/day). Women were classified in two groups according to their baseline HOMA-IR: IR $(n=64)$ and non-IR $(n=121)$. Results: At baseline, IR and non-IR groups had similar BMI (26.7 vs. $\left.26.3 \mathrm{~kg} / \mathrm{m}^{2} ; \mathrm{p}=0.21\right)$, but the IR group presented with higher waist circumference $(82.7$ vs. $80.8 \mathrm{~cm} ; \mathrm{p}=0.02)$ and showed greater weight loss after 12 months of follow-up ( -1.6 vs. $-1.1 \mathrm{~kg} ; \mathrm{p}=0.01)$, mainly among those in a high-GI diet ( $-2.1 \mathrm{vs.}-1.0 \mathrm{~kg} ; \mathrm{p}=0.005)$ compared to the non-IR group $(-1.4$ vs. $-0.8 \mathrm{~kg} ; \mathrm{p}=0.04)$. Conclusions: The high-GI group showed statistically significant higher reduction in body weight, mainly among those women with baseline IR . Low-GI diet did not facilitate weight loss neither in IR women nor in non-IR women.
\end{abstract}

Copyright (C) 2012 S. Karger AG, Basel

\section{Introduction}

It has been postulated that insulin resistance (IR) plays an important role in body weight regulation [1]. A hypothesis brought up by Eckel [1] suggests that IR serves as a physiologic preventative measure against future weight gain by allowing preferential fatty acid mobilization and oxidation, and through the direct effects of insulin on the central nervous 
system, resulting in satiety and reduced food intake over the time. On the other hand, other studies have provided a body of evidence against this hypothesis, showing that IR could promote weight gain or had no effects on weight change [2-5]. These conflicting results could be attributed to the differences in study designs, different interventions to promote weight loss such as diet, exercise or both, and sample characteristics. Furthermore, many factors that influence insulin dynamics (e.g. type of diet) may theoretically interact with subject-specific characteristics to influence weight change.

Many types of diets have been proposed to promote weight loss, and most of them showed similar results, as observed in a study conducted by Sacks et al. [6]. The glycemic index (GI) diet could be an alternative dietary intervention that classifies carbohydrate intake according to blood glucose responses [7]. Even though the GI had relevance in lipid and glycemic control, the effect of GI on weight management remains a controversial issue [8-12]. A meta-analysis published by Thomas et al. [13] showed a greater weight loss associated to low GI diets in short-term studies, although in this analysis studies have not account for one important methodological issue, the macronutrient composition of the diet, mainly protein and fiber, and also did not differentiate glycemic load from GI. Other studies in which low GI compared to high GI were matched on macronutrient composition and fiber have not shown any effect on weight change, although positive effects on serum lipids were confirmed $[8,12,14]$. Recently, Larsen et al. [15] conducted a large randomized study evaluating the effects of different GI diet on weight maintenance and showed a potential benefit of low-GI diet on maintenance of weight loss after 6 months of follow-up.

An important factor that could be related to the effectiveness of GI diet on weight change is the insulin sensitivity, given the direct influence of GI on insulin secretion [16]. Wolever and Mehling [17] studied the effects of different GI diets on weight change in subjects with impaired glucose tolerance and found a greater weight loss for the high-GI group after 4 months of follow-up. On the other hand, in a small clinical trial, Pittas et al. [18] showed that high baseline insulin, a typical characteristic of IR, was positively associated with weight loss among participants on a low-GI diet, and the reverse was observed in those with low insulin at baseline.

In our study comparing low- to high-GI diets matched on other dietary constituents in each meal [8], one third of women were classified as insulin-resistant, allowing us to test the hypothesis that IR at baseline could modify the association between low GI and weight loss during the follow-up. We hypothesized that low-GI diet could be most effective among IR subjects, given the higher fasting insulin in this group, while a high-GI diet could be more effective among non-IR subjects, based on lower fasting insulin.

\section{Material and Methods}

The present study is a secondary analysis of a randomized controlled trial primarily designed to compare the effects of a low- and high-GI diet on weight change. The full description and results of dietary intervention have been published elsewhere [8]. In short, 203 middle-aged healthy women (25-45 years) with a BMI of 23-29.9 $\mathrm{kg} / \mathrm{m}^{2}$ were recruited for the study which aimed at a small weight loss during the follow-up. The study was approved by the Institutional Review Boards of Harvard School of Public Health and of State University of Rio de Janeiro.

\section{Dietary Intervention}

Dietary counseling was based on a small energy restriction (100-300 kcal/day) with 26-28\% of energy as fat. Individual nutritionist counseling was given every month with menus and exchange lists provided. For each low-GI diet meal there was an average difference of 40 units of GI compared to the high-GI diet based on published GI values for healthy individuals [19], using white bread as the standard GI of $100 \%$. The overall GI was calculated by multiplying the carbohydrate intake of each food by its GI, 
summing up the products for all foods and dividing the sum by the total carbohydrate intake. Main items included in the experimental diet included beans, parboiled rice as well as fruits of low GI such as plums, apple, strawberry, orange, tangerine, pear, peach, fig, and guava.

Subjects were instructed to eat three meals and three snacks according to a 6-day menu plan. Instructions also included limiting to a minimum all candies, added sugar, and sodas, except for the weekly day free of diet.

Measurements

Weight was measured monthly. Waist and hip circumference, body composition, and fasting blood samples were collected at baseline and after 3, 6, and 12 months of follow-up. All measurements were performed in the morning, and blood samples were collected after a 10-hour fast. Aliquots of plasma and serum were isolated from the blood samples and frozen at $-70{ }^{\circ} \mathrm{C}$ within $2 \mathrm{~h}$ after being drawn. Height was measured to the nearest $0.5 \mathrm{~cm}$ with a wall-mounted stadiometer, and body weight was measured by using the same calibrated digital scale for all participants. Circumferences were determined with the participants standing and were taken at the largest girth of the hip and smallest girth of the waist.

Food intake was based on the food frequency questionnaire developed and validated in the adult Brazilian population [20], and it was measured at baseline and after 3-, 6-, and 12-month follow-up.

Glucose were measured using GoldAnalisa kits (Gold Analisa Diagnóstica Ltd., Belo Horizonte, Brazil) with an intra-assay CV varying from $0.9 \%$ to $1.2 \%$, and an inter-assay CV varying from $1.9 \%$ to $2.7 \%$. Serum insulin concentration was determined by radioimmunoassay using a ImmuChem ${ }^{\mathrm{TM}} 125 / \mathrm{RIA}$ kit (ImmuChem S.A. Voz-Ramet, Belgium) with an intra-assay CV varying from $4.2 \%$ to $8.2 \%$, and an interassay CV varying from $6.4 \%$ to $8.8 \%$. Relative insulin resistance (HOMA-IR) was estimated according to the formula ((glucose in $\mathrm{mmol} / \mathrm{l} \times$ insulin in $\mu \mathrm{U} / \mathrm{ml}) / 22.5$ ).

\section{Data Analysis}

Previous results of this study showed that low-GI diet did not facilitate long-term (18 months) weight loss compared to high-GI diet; in the present analysis, we used the first 12 months of follow-up due to the important weight regain after this time frame. Of the 203 women included in the primary study, 185 had insulin baseline values and were included in this secondary analysis. The Brazilian criteria for IR, which state a cut-off value of 2.71 [21], were used to classify women in two groups according to the baseline HOMA-IR: IR $(\mathrm{n}=64)$ and non-IR $(\mathrm{n}=121)$.

Baseline characteristics of groups were compared using Student's t-test. Analysis of changes over time for parallel groups with repeated measurement used the PROC MIXED in SAS (version 9.1; SAS Institute Inc, Cary, NC, USA). This analysis included all subjects regardless of loss to follow-up or compliance. The effects of diet stratified by IR status at baseline included time, diet and time $\times$ diet interaction. The term of interest was time $\times$ diet interaction, which estimates the rate of changes in the outcomes. Residual plots of all models were examined, and their distributions did not show major deviations from regression assumptions.

\section{Results}

Baseline characteristics of the participants were compared in relation to IR and assigned diets (table 1). Compared to IR group, the non-IR group showed very similar values of height, weight, BMI, and hip circumference but statistically significant lower values of waist, waistto-hip ratio, glucose, insulin, and HOMA-IR, as expected. When tnon-IR and IR groups were further stratified by GI diet, there were no differences according to diet in both groups (table 1).

Women classified as insulin-resistant at baseline had greater weight loss after 12 months of follow-up in comparison to non-IR (-1.6 vs. $-1.1 \mathrm{~kg} ; \mathrm{p}=0.01)$, independently of the dietary intervention assigned. During follow-up, changes were more pronounced in women on the high-GI diet than in women on the low-GI diet. These differences were statistically significant for weight and BMI and were greater among the IR group (table 2). No differences for energy intake were found between diet groups during the follow-up $(p>0.4)$. 
Table 1. Means (SD) of baseline characteristics by IR and diet

\begin{tabular}{|c|c|c|c|c|c|c|}
\hline \multirow[t]{2}{*}{ Variable } & \multicolumn{2}{|l|}{ NIR (n = 121) } & \multirow[t]{2}{*}{$\mathrm{p}$ value $^{\mathrm{a}}$} & \multicolumn{2}{|l|}{ IR $(n=64)$} & \multirow[t]{2}{*}{$\mathrm{p}$ value ${ }^{\mathrm{a}}$} \\
\hline & $\operatorname{LGI}(n=61)$ & HGI $(n=60)$ & & LGI (n = 32) & HGI $(n=32)$ & \\
\hline Age, years & $\begin{array}{l}37.4(5.4) \\
37.3(5.1)\end{array}$ & $37.4(5.7)$ & 0.91 & $\begin{array}{l}37.7(5.3) \\
37.8(5.3)\end{array}$ & $37.6(5.4)$ & $\begin{array}{l}0.70 \\
0.83\end{array}$ \\
\hline Body weight, kg & $\begin{array}{l}67.9(6.9) \\
67.5(7.0)\end{array}$ & $68.3(6.9)$ & 0.50 & $\begin{array}{l}68.6(7.2) \\
68.1(6.2)\end{array}$ & $69.0(8.2)$ & $\begin{array}{l}0.53 \\
0.60\end{array}$ \\
\hline Height, cm & $\begin{array}{l}160.5(6.0) \\
159.8(5.7)\end{array}$ & $161.1(6.3)$ & 0.22 & $\begin{array}{l}160.1(6.6) \\
159.7(6.6)\end{array}$ & $160.5(6.7)$ & $\begin{array}{l}0.72 \\
0.61\end{array}$ \\
\hline Waist circumference, $\mathrm{cm}$ & $\begin{array}{l}80.9(5.37) \\
80.6(5.7)\end{array}$ & $80.9(5.1)$ & 0.81 & $\begin{array}{l}82.7(4.9) \\
82.6(5.0)\end{array}$ & $82.7(5.0)$ & $\begin{array}{l}0.02 \\
0.92\end{array}$ \\
\hline Hip circumference, $\mathrm{cm}$ & $\begin{array}{l}104.5(5.7) \\
104.5(5.6)\end{array}$ & $104.4(5.9)$ & 0.96 & $\begin{array}{l}103.9(5.7) \\
103.4(5.8)\end{array}$ & $104.3(5.8)$ & $\begin{array}{l}0.52 \\
0.54\end{array}$ \\
\hline BMI, $\mathrm{kg} / \mathrm{m}^{2}$ & $\begin{array}{l}26.3(2.0) \\
26.4(1.8)\end{array}$ & $26.3(2.1)$ & 0.83 & $\begin{array}{l}26.7(1.8) \\
26.7(1.7)\end{array}$ & 26.7 (1.9) & $\begin{array}{l}0.21 \\
0.93\end{array}$ \\
\hline Waist-to-hip ratio & $\begin{array}{l}0.77(0.05) \\
0.77(0.05)\end{array}$ & $0.78(0.05)$ & 0.68 & $\begin{array}{l}0.80(0.06) \\
0.80(0.06)\end{array}$ & $0.79(0.05)$ & $\begin{array}{l}0.004 \\
0.68\end{array}$ \\
\hline Glucose, mg/dl & $\begin{array}{l}82.0(9.8) \\
81.9(11.2)\end{array}$ & $82.0(8.1)$ & 0.95 & $\begin{array}{l}93.3(20.0) \\
91.4(14.0)\end{array}$ & $95.2(24.6)$ & $\begin{array}{l}<0.001 \\
0.46\end{array}$ \\
\hline Insulin, $\mu \mathrm{U} / \mathrm{ml}$ & $\begin{array}{l}9.5(2.0) \\
9.47(2.00)\end{array}$ & $9.47(2.05)$ & 0.98 & $\begin{array}{l}15.9(4.3) \\
15.66(4.36)\end{array}$ & $16.09(4.38)$ & $\begin{array}{l}<0.001 \\
0.70\end{array}$ \\
\hline HOMA-IR & $\begin{array}{l}1.90(0.41) \\
1.90(0.40)\end{array}$ & $1.91(0.42)$ & 0.90 & $\begin{array}{l}3.57(0.94) \\
3.50(1.01)\end{array}$ & $3.63(0.86)$ & $\begin{array}{l}<0.001 \\
0.57\end{array}$ \\
\hline
\end{tabular}

LGI = Low glycemic index; HGI = high glycemic index.

at-test.

\section{Discussion}

An important finding of the present study was the influence of IR on rate of weight change. Women classified as insulin-resistant showed a greater weight loss after 12 months of follow-up in comparison with non-IR women. Some investigators found an association between IR and weight loss, and it has been proposed that IR is a physiological adaptation that limits fat deposition, increases lipolysis, and leads to weight stabilization [22]. In addition, insulin secretion may reduce weight gain through the direct effects of insulin on the central nervous system by inducing satiety and reducing food intake $[1,23]$. In accordance with our findings, Evangelou et al. [24] examined the influence of IR on weight change during a follow-up study of obese women with metabolic syndrome submitted to a caloric restriction and found that patients in the highest quartile of HOMA-IR at baseline lost more weight than the rest of the group.

Most of the studies on the effect of IR on weight change compared groups with different IR but also differences in BMI. Our sample has the important characteristic of a similar overall adiposity (measured by BMI) in both IR groups but greater difference in waist 
Table 2. Crude means (SD) and adjusted changes from baseline $(\Delta)$ for anthropometric characteristics during the follow-up by IR and diet

\begin{tabular}{|c|c|c|c|c|c|c|c|}
\hline & \multicolumn{2}{|c|}{$\begin{array}{l}3 \text { months } \\
(\mathrm{NIR}=72, \mathrm{IR}=39)\end{array}$} & \multicolumn{2}{|c|}{$\begin{array}{l}6 \text { months } \\
(\mathrm{NIR}=51, \mathrm{IR}=28)\end{array}$} & \multicolumn{2}{|c|}{$\begin{array}{l}12 \text { months } \\
(\text { NIR }=65, \text { IR }=41)\end{array}$} & \multirow[t]{2}{*}{$\mathrm{p}$ value $^{\mathrm{a}}$} \\
\hline & mean (SD) & $\Delta^{\mathrm{a}}$ & mean (SD) & $\Delta^{\mathrm{a}}$ & mean (SD) & $\Delta^{\mathrm{a}}$ & \\
\hline \multicolumn{8}{|c|}{ Body weight, $\mathrm{kg}$} \\
\hline Non-IR & & & & & & & 0.04 \\
\hline LGI & $66.5(8.4)$ & -0.4 & $65.7(7.4)$ & -0.6 & $65.5(7.6)$ & -0.8 & \\
\hline HGI & $67.7(6.8)$ & -0.5 & $67.7(8.0)$ & -0.8 & $68.5(6.8)$ & -1.4 & \\
\hline IR & & & & & & & 0.005 \\
\hline LGI & $68.4(7.2)$ & -0.4 & $67.3(6.0)$ & -0.6 & $67.8(6.1)$ & -1.0 & \\
\hline HGI & $66.9(6.6)$ & -0.5 & $68.3(9.9)$ & -1.1 & $65.5(5.6)$ & -2.1 & \\
\hline \multicolumn{8}{|c|}{$B M I, \mathrm{~kg} / \mathrm{m}^{2}$} \\
\hline Non-IR & & & & & & & 0.05 \\
\hline LGI & $26.2(1.8)$ & -0.2 & $26.1(1.8)$ & -0.3 & $25.8(2.1)$ & -0.3 & \\
\hline HGI & $25.8(2.3)$ & -0.2 & $25.7(2.6)$ & -0.3 & $25.9(2.4)$ & -0.5 & \\
\hline IR & & & & & & & 0.007 \\
\hline LGI & $26.8(2.1)$ & -0.2 & $26.2(1.4)$ & -0.2 & $25.8(1.69)$ & -0.4 & \\
\hline HGI & $26.0(1.9)$ & -0.2 & $26.4(2.0)$ & -0.4 & $25.6(1.85)$ & -0.8 & \\
\hline \multicolumn{8}{|c|}{ Waist circumference, $\mathrm{cm}$} \\
\hline Non-IR & & & & & & & 0.07 \\
\hline LGI & $80.3(6.8)$ & -0.4 & 79.8 (5.9) & -0.5 & $78.5(6.1)$ & -0.7 & \\
\hline HGI & $80.0(5.1)$ & -0.4 & 80.5 (5.7) & -0.9 & $79.1(5.1)$ & -1.8 & \\
\hline IR & & & & & & & 0.56 \\
\hline LGI & $82.6(5.1)$ & -0.7 & $82.5(4.0)$ & -1.3 & $79.4(3.4)$ & -2.2 & \\
\hline HGI & $81.0(5.0)$ & -0.9 & $81.2(5.1)$ & -1.2 & $81.1(6.0)$ & -2.0 & \\
\hline
\end{tabular}

LGI = Low glycemic index; HGI = high glycemic index .

${ }^{a}$ Model based on repeated measures includes time, diet and time $\times$ diet interaction adjusted for baseline values.

circumference. The subcutaneous adipose depot is the primary store site for fat, and an enlargement of subcutaneous fat depot leads to an increase of IR, limiting lipid deposition at the subcutaneous site and leading to an increased uptake of triglycerides in the visceral adipose depot $[25,26]$. In our study, the IR group had greater waist circumference and waistto-hip ratio (a surrogate for visceral fat), and studies have been showing that visceral adipose tissue is more resistant to antilipolytic effects of insulin than subcutaneous fat [27]. Conversely, catecholamines have a lipolytic effect that predominates on the adipocytes of visceral tissue, leading a greater lipolysis [28]. Therefore, it could be postulated that the IR group, who had greater visceral fat mass, was more prone to greater weight loss compared to women of same adiposity without IR.

Whether subgroups in the population respond better to different diets is an unanswered important question, and only few studies examined whether the presence of IR influenced the weight loss response to diet [29, 30]. In addition, the results of studies that investigated the effects of IR status on weight loss in individuals submitted to different GI diets are still controversially discussed [16, 31]. Our results showed that low-GI diet did not facilitate weight loss and that IR women receiving the high-GI diet had the greatest weight loss. In a small clinical trial, Pittas et al. [18] examined the effects of diets with different glycemic loads and the influence of baseline insulin on weight change. They found that individuals with rela- 
tively greater insulin secretion lost more weight when assigned to a low glycemic load than those assigned to a high glycemic load diet, but there was no differential effect of the two diets on weight loss in individuals who had relatively lower insulin secretion. The authors postulated that high-glycemic-load diet increases postprandial hyperinsulinemia, which favors fatty acid uptake and inhibition of lipolysis, thus increasing energy storage and leading to weight gain. On the other hand, Wolever and Mehling [17] showed a greater weight loss in subjects with impaired glucose tolerance submitted to high-GI diet after 4-month follow-up.

Insulin sensitivity and secretion may interact with each other to influence weight change, as showed by Sigal et al. [32]. In this study, those subjects with high insulin secretion without IR gained more weight than those with IR. Therefore, the effect of insulin on weight change depends on whether insulin secretion is an appropriate response to IR. Insulin hypersecretion can promote weight loss as an appropriate response for IR. However, if insulin hypersecretion is excessive in relation to iIR, hyperinsulinemia may promote weight gain [16]. This balance could explain the results found by Pittas et al. [18], in which non-IR participants and with greater insulin secretion had weight gain. In our sample, the IR group had fasting insulin at baseline almost two times the concentration of insulin in the non-IR group, and an increase in insulin secretion in response to a high-GI diet in the IR group may have exacerbate the catabolic effects of this hormone, leading to a weight loss.

Limitations of our study include the use of the HOMA-IR index to classify women according to baseline IR. Although not a golden standard, HOMA-IR is feasible and has been validated by several studies [33,34]. In addition, waist circumference is not a direct measure of visceral fat, but it has also been used in many studies as a proxy measure.

In summary, findings in this report indicate that low-GI diet does not facilitate weight loss, independently of baseline IR status. Instead, the high-GI group showed a greater reduction in body weight, mainly among those women with baseline IR. The influence of insulin dynamics on weight change is still unclear and needs to be taken into consideration in future studies.

\section{Acknowledgements}

Research relating to this study was funded by grant R03 TW005773-03 from National Institutes of Health - NIH, and grant 500404/2003-8 from Brazilian National Research Council - CNPq.

\section{Disclosure Statement}

The authors declare no conflict of interest.

\section{References}

- 1 Eckel RH: Insulin resistance: an adaptation for weight maintenance. Lancet 1992;340:1452-1453.

- 2 Howard BV, Adams-Campbell L, Allen C, Black H, Passaro M, Rodabough RJ, Rodriguez BL, Safford M, Stevens VJ, Wagenknecht LE: Insulin resistance and weight gain in postmenopausal women of diverse ethnic groups. Int J Obes Relat Metab Disord 2004;28:1039-1047.

- 3 Johnson MS, Figueroa-Colon R, Huang TT, Dwyer JH, Goran MI: Longitudinal changes in body fat in African American and Caucasian children: influence of fasting insulin and insulin sensitivity. J Clin Endocrinol Metab 2001;86:3182-3187.

4 Wedick NM, Snijder MB, Dekker JM, Heine RJ, Stehouwer CD, Nijpels G, van Dam RM: Prospective investigation of metabolic characteristics in relation to weight gain in older adults: the Hoorn Study. Obesity (Silver Spring) 2009;17:1609-1614.

5 Votruba SB, Jensen MD: Insulin sensitivity and regional fat gain in response to overfeeding. Obesity (Silver Spring) 2011;19:269-275. 
- 6 Sacks FM, Bray GA, Carey VJ, Smith SR, Ryan DH, Anton SD, McManus K, Champagne CM, Bishop LM, Laranjo N, Leboff MS, Rood JC, de Jonge L, Greenway FL, Loria CM, Obarzanek E, Williamson DA: Comparison of weightloss diets with different compositions of fat, protein, and carbohydrates. N Engl J Med 2009;360:859-873. Jenkins DJ, Wolever TM, Taylor RH, Barker H, Fielden H, Baldwin JM, Bowling AC, Newman HC, Jenkins AL, Goff DV: Glycemic index of foods: a physiological basis for carbohydrate exchange. Am J Clin Nutr 1981;34: 362-366.

8 Sichieri R, Moura AS, Genelhu V, Hu F, Willett WC: An 18-mo randomized trial of a low-glycemic-index diet and weight change in Brazilian women. Am J Clin Nutr 2007;86:707-713.

- 9 Brand-Miller JC, Holt SH, Pawlak DB, McMillan J: Glycemic index and obesity. Am J Clin Nutr 2002;76:281S285S.

$\checkmark 10$ Flint A, Moller BK, Raben A, Pedersen D, Tetens I, Holst JJ, Astrup A: The use of glycaemic index tables to predict glycaemic index of composite breakfast meals. Br J Nutr 2004;91:979-989.

11 Ludwig DS: The glycemic index: physiological mechanisms relating to obesity, diabetes, and cardiovascular disease. JAMA 2002;287:2414-2423.

-12 Sloth B, Krog-Mikkelsen I, Flint A, Tetens I, Bjorck I, Vinoy S, Elmstahl H, Astrup A, Lang V, Raben A: No difference in body weight decrease between a low-glycemic-index and a high-glycemic-index diet but reduced LDL cholesterol after 10-wk ad libitum intake of the low-glycemic-index diet. Am J Clin Nutr 2004;80:337-347.

13 Thomas DE, Elliott EJ, Baur L: Low glycaemic index or low glycaemic load diets for overweight and obesity. Cochrane Database Syst Rev 2007:CD005105.

14 Vrolix R, Mensink RP: Effects of glycemic load on metabolic risk markers in subjects at increased risk of developing metabolic syndrome. Am J Clin Nutr 2010;92:366-374.

$\checkmark 15$ Larsen TM, Dalskov SM, van Baak M, Jebb SA, Papadaki A, Pfeiffer AF, Martinez JA, Handjieva-Darlenska T, Kunesova M, Pihlsgard M, Stender S, Holst C, Saris WH, Astrup A: Diets with high or low protein content and glycemic index for weight-loss maintenance. N Engl J Med 2010;363:2102-2113.

16 Pittas AG, Roberts SB: Dietary composition and weight loss: can we individualize dietary prescriptions according to insulin sensitivity or secretion status? Nutr Rev 2006;64:435-448.

$\checkmark 17$ Wolever TM, Mehling C: High-carbohydrate-low-glycaemic index dietary advice improves glucose disposition index in subjects with impaired glucose tolerance. Br J Nutr 2002;87:477-487.

18 Pittas AG, Das SK, Hajduk CL, Golden J, Saltzman E, Stark PC, Greenberg AS, Roberts SB: A low-glycemic load diet facilitates greater weight loss in overweight adults with high insulin secretion but not in overweight adults with low insulin secretion in the calerie trial. Diabetes Care 2005;28:2939-2941.

$\checkmark 19$ Foster-Powell K, Holt SH, Brand-Miller JC: International table of glycemic index and glycemic load values: 2002. Am J Clin Nutr 2002;76:5-56.

20 Sichieri R, Everhart JE: Validity of a Brazilian food frequency questionnaire against dietary recalls and estimated energy intake. Nutr Res 1998;18:1649-1659.

-21 Geloneze B, Repetto EM, Geloneze SR, Tambascia MA, Ermetice MN: The threshold value for insulin resistance (HOMA-IR) in an admixtured population IR in the Brazilian Metabolic Syndrome study. Diabetes Res Clin Pract 2006; 72:219-220.

22 Swinburn BA, Nyomba BL, Saad MF, Zurlo F, Raz I, Knowler WC, Lillioja S, Bogardus C, Ravussin E: Insulin resistance associated with lower rates of weight gain in pima indians. J Clin Invest 1991;88:168-173.

23 Porte D Jr, Seeley RJ, Woods SC, Baskin DG, Figlewicz DP, Schwartz MW: Obesity, diabetes and the central nervous system. Diabetologia 1998;41:863-881.

-24 Evangelou P, Tzotzas T, Christou G, Elisaf MS, Kiortsis DN: Does the presence of metabolic syndome influence weight loss in obese and overweight women? Metab Syndr Relat Disord 2010;8:173-178.

25 Despres JP, Lemieux I: Abdominal obesity and metabolic syndrome. Nature 2006;444:881-887.

-26 Ali AT, Ferris WF, Naran NH, Crowther NJ: Insulin resistance in the control of body fat distribution: a new hypothesis. Horm Metab Res 2011;43:77-80.

27 Ibrahim MM: Subcutaneous and visceral adipose tissue: structural and functional differences. Obes Rev 2010;11:11-18.

28 Lafontan M, Berlan M: Do regional differences in adipocyte biology provide new pathophysiological insights? Trends Pharmacol Sci 2003;24:276-283.

29 Cornier MA, Donahoo WT, Pereira R, Gurevich I, Westergren R, Enerback S, Eckel PJ, Goalstone ML, Hill JO, Eckel RH, Draznin B: Insulin sensitivity determines the effectiveness of dietary macronutrient composition on weight loss in obese women. Obes Res 2005;13:703-709.

-30 McLaughlin T, Abbasi F, Carantoni M, Schaaf P, Reaven G: Differences in insulin resistance do not predict weight loss in response to hypocaloric diets in healthy obese women. J Clin Endocrinol Metab 1999;84:578-581.

31 Pittas AG, Roberts SB, Das SK, Gilhooly CH, Saltzman E, Golden J, Stark PC, Greenberg AS: The effects of the dietary glycemic load on type 2 diabetes risk factors during weight loss. Obesity (Silver Spring) 2006;14: 2200-2209.

-32 Sigal RJ, El-Hashimy M, Martin BC, Soeldner JS, Krolewski AS, Warram JH: Acute postchallenge hyperinsulinemia predicts weight gain: a prospective study. Diabetes 1997;46:1025-1029.

-33 Matthews DR, Hosker JP, Rudenski AS, Naylor BA, Treacher DF, Turner RC: Homeostasis model assessment: insulin resistance and beta-cell function from fasting plasma glucose and insulin concentrations in man. Diabetologia 1985;28:412-419.

34 Wallace TM, Levy JC, Matthews DR: Use and abuse of HOMA modeling. Diabetes Care 2004;27:1487-1495. 